Natalia MIRONOVA ${ }^{1}$

Galina KALDA ${ }^{2}$

Oleg LISHCHUK ${ }^{3}$

\title{
PHYTOMELIORATIVE INFLUENCE OF THE MACROPHYTES OF DIFFERENT ECOLOGICAL GROUPS OVER THE OXYGENE REGIME IN THE TECHNOGENIC LAKES OF THE SMALL POLISSYA OF UKRAINE
}

\begin{abstract}
The article presents the results of determining the characteristics of the oxygen regime in the macrophytes thickets of different ecological groups: of submerged (Cerat ophyllum demersum L.), floating (Potamogeton natans L., Nuphar lutea $(L)$. Smith.) and air-water (Phragmites australis (Cav.) Trin. ex Steud.) in technogenic lakes of Small Polissya of Ukraine. Physiographic area of Small Polissya located mainly in the western regions of Ukraine, and a small part - in Poland, and differs plain relief, high humidification, closeness of groundwater from surface. Technogenic lakes were formed by sand mining using dredges as result underwater extraction in aqueous career. They have an age of between 30 and 60 years, can be flowthrough and non-flow-through. Soluble oxygen, temperature and oxygen saturation were measured by the device Oxi 330i/SET. The largest concentration of oxygen is determined in areas of lakes occupied by submerged vegetation. In thickets of airwater and floating vegetation the oxygen content is almost identical and with the depth it gradually decreases. In the thickets macrophytes the oxygen regime is affected by the degree of flow-through and age of lakes. In the «younger» nonflowing lakes of 30-35 years of age the oxygen concentration is the largest, the lowest oxygen concentration is in the old lakes. According to the determination of dissolved oxygen at different depths and in the bottom layer we proved an active development of eutrophication processes in non-flowing technogenic lakes aged about 60 years.
\end{abstract}

Keywords: oxygen content, technogenic lakes, submerged, floating and air-and-water macrophytes

\footnotetext{
${ }^{1}$ Natalia Mironova, National Forestry University of Ukraine, Lviv, Ukraine, 26 Pribuzhska St., apt. 25, Khmelnitsky Ukraine, tel. +0380671177093, e-mail: mironova72@ mail.ru

2 Autor do korespondencji/corresponding author: Galina Kalda, Rzeszow University of Technology, 35-084 Rzeszow, 2 Poznanska St., tel. (17) 8651068, e-mail: kaldagal@prz.edu.pl

${ }^{3}$ Oleg Lishchuk, State Environmental Inspectorate in Khmelnitsky Region, Khmelnytsky, Ukraine, 17 Matrosov St., tel. +0380678023871, e-mail: khmlab@mail.ru
} 


\section{Introduction}

Technogenic geochemical and geomorphological transformation of land plots, on which the mining works are conducted, is the major factor of destabilization of natural territorial complexes. Therefore, their re-naturalization under the European Landscape Convention [1] is a priority for sustainable development in these areas.

One of the least studied effects of open pit mining is the formation of water reservoirs in the pit of the metallic minerals "wet" extraction, primarily sand, which commonly resemble lakes. Today the majority of scientific research is aimed at studying the negative impact over the environment and remediation measures for dry pits.

New items of hydrographic network of man-made landscape differ from both natural and man-made (anthropogenic) water bodies. The latter (eg. reservoirs, ponds) were created to carry out certain economic functions and were built to meet the requirements as close as possible to natural analogues. Formation of the reservoirs (lakes) in the result of mining activities is the result of technological developments, because in fact they are man-made, since their formation was influenced by technological and economic factors. In this regard, man-made lakes are different from natural ones by morphological structure, specific chemical composition of water and the bottom, broken edafotop and vegetation in the coastal zone.

The final stage of the operation of any career is its reclamation, which consists of technical and biological units [2], but often under conditions of low toxic environment (which is typical for sand extraction) this step is ignored, and the restoration of plant continuum is done due to self-development processes.

Phytocoenotic cover or autotrophic block of any system is biospherically active. In making their own ecological environment, vegetation performs numerous functions of biosphere, the results of which are phytomeliorative environment optimization [3]. Based on the analysis of the literature [4-9] we distinguished the following four functions of phytomeliorative vegetation optimization of man-made water lakes (Fig. 1).

Together with surface runoff in emerging coastal abrasion the reservoirs receive large amounts of suspended and slightly soluble organic and mineral substances. Vegetation acts as a mechanical filter, that stipulates reduction in flow velocity in the area of undergrowth and sedimentation of suspended particles. Influenced by phyto-filtration the water clarity increases and diminishes its salinity. Degradation and mineralization of complex organic compounds to simple and friendly ones with plants participation is done in an aqueous medium and in ecotonic area. This process in the life of the reservoir has a leading role.

Detoxification function lies in the fact that in the result of metabolism the higher aquatic plants release physiologically active substances such as volatile into the environment. This reduces the number of pathogenic organisms. Ho- 
wever, plants remove from the water and the bottom substrate, which is represented by deposits of minerals extracted, not only nutrients, but also compounds of heavy metals.



Fig. 1. Phyto-meliorative function of vegetation in technogenic lakes

Rys. 1. Fitomelioratywne funkcje roślinności w jeziorach technogenicznych

Higher aquatic vegetation has a favorable effect on the oxygen regime of reservoirs. The oxygen content in the water increases in photosynthesis, resulting, in turn, in rapid oxidation of organic matter and acceleration of the process of nitrification, increased consumption of free carbon dioxide and so on by the photo-synthetics. The latter type of phytomeliorative effects (production of oxygen by plants) is essential to man-made lakes that are fueled by underground sources, as is known, the soil and groundwater have low concentrations of dissolved oxygen [10]. This in turn may prevent the development of aquatic organisms and, consequently, the formation of a complete hydro ecosystem capable of recreational and environmental functions.

In the scientific literature there is enough information on the oxygen regime in the bush macrophytes in natural $[11 \div 13]$ and man-made $[14,15]$ waters, but man-made ponds with its specific set of hydrometric, physical-chemical and hydrobiological parameters are hardly explored. Therefore, the aim of the research was to determine the oxygen regime of man-made lakes and the impact of plant groups belonging to different ecological groups.

\section{Materials and methods of research}

The study was conducted in the period of maximum development of higher aquatic vegetation in man-made lakes of different ages both non-flowing and with weak water exchange.

Soluble oxygen, temperature and oxygen saturation were measured by the device Oxi 330i / SET. The accuracy of the instrument for dissolved oxygen is $0.5 \%$ of the value which was obtained by measurement. Due to the possibility of daily dynamics of the oxygen concentration in the water in order to reduce the error the measurements were performed in the afternoon during $11 \div 16$ hours. 
Measurements were carried out in the existing populations of typical technological lake plants which belong to environmental groups of submerged $(\mathrm{Ce}$ ratophyllum demersum L.), floating (Potamogeton natans L., Nuphar lutea $(L)$. Smith.) and air-water (Phragmites australis (Cav.) Trin. ex Steud.) plants.

\section{Research results and discussion}

Physiographic area of Small Polissya is located between Volyn Upland steppe in the north, north-west Roztocze and Podillya Upland steppe in the south-east.

The Small Polissya area has a triangle shape, the bigger side of which is located on the north side, and the opposite corner from it reaches an ancient settlement Zvenygorod in Peremyshl rayon of Lviv oblast. The west corner of the «triangle» is located in Tomaszów Lubelski in Poland, where the river Solokiya originates (the left tributary of the river Western Bug). This physicalgeographic zone is characterized by high moisture, mild winters and moderately warm summers. The particular features of the geomorphological structure of the plains are stipulated by local climatic differences. Thus, the amount of rainfall in Small Polissya is greater and equals to $650 \div 740 \mathrm{~mm}$, which is $11 \div 14 \%$ higher than in adjacent areas [16]. Such excess amount of precipitation is explained by higher forestation and water-logged areas. In the natural environment of Small Polissya the important role is played by groundwater. The aquifer in anthropogenic sediments lies at a depth of $0.5 \mathrm{~m}$.

Technogenic lakes which are located in Small Polissya of Ukraine, were formed by sand mining dredge. The acquisition of this territory as raw materials base began in the early 20th century with the extraction of construction materials of local significance. In areas close to groundwater the extraction of sand in the upper layer was carried out in dry conditions. By reducing the working depth of the career it was done by the way of underwater extraction in aqueous career. Collection of sand was carried to reaching a depth of water to $15 \mathrm{~m}$. After the termination of the career use there remained man-made water bodies like lakes, with devastated coastal zone within the career field and the adjacent territory.

The studied reservoirs are classified according to the area as small water surface areas of less than $1 \mathrm{~km}^{2}$. Considering the genesis of man-made lakes, the structure of the created lakes is complex. In general, according to the shape they can be attributed to two groups - elongated and oval with uneven coastline, which is due to the spatial localization of specific minerals which are put out in the pits. It explains the absence of shallow water at some developed coastal areas. The lakes have a mixed type with a predominance of underground water supply and slope runoff, partly due to rainfalls.

In the conditions of newly created man-made hydrotopes there were created lake ecosystems that were trying to develop according to natural laws, with certain characteristics are similar to natural analogues. As you know, the main spe- 
cific feature of the lakes is a positive balance of matter and energy. The natural process of «aging» of the lake lies in the accumulation of auto-and allohtonic organic and mineral matter, shoaling and full overgrowing. In lakes with flowing waters there is the outflow of water, allowing the ecosystem to maintain a stable level and not to «age». In lakes where there are no such external factors, there is a gradual accumulation of nutrients, resulting in the fact that an oligotrophic lake becomes eutrophic. The latter ones while aging are filled with bottom sediments, increase productivity, and experience natural eutrophication [17].

An adequate indicator of the degree of eutrophication is oxygen in summer [18]. Dissolved oxygen in the water is one of the most critical parameters characterizing the suitability of water for drinking and industrial water supply, as well as habitat for organisms. Its content largely determines the water quality and intensity of the processes occurring in the reservoir - pollution and purification, decomposition of organic matter, life hydrobionts. The oxygen concentration, determined in water, is the resulting value, which depends on complex countervailing processes in the water column and at the boundaries between phases. Today it is proved that photosynthetic aeration often exaggerates the atmospheric one [10]. Therefore, determining the concentration of dissolved oxygen was conducted at sites in the intertidal niches of airy, floating and submerged aquatic vegetation in the man-made lakes of different age that are both flowing and non-flowing water reservoirs.

To conduct the research and analysis the lakes were divided into four groups.

The 1st group - non-flowing lakes formed about 60 years ago. Their depth during the development of the lake after sand extraction decreased from $15 \mathrm{~m}$ to $3 \div 5 \mathrm{~m}$ due to silting of sand that came from the coastal zone due to active erosion, as well as laying of organic remnants, the bottom being sandy and muddy. Overgrowing populations of higher aquatic plants of different ecological groups is $50 \div 65 \%$ (Fig. 2).

The 2nd group makes younger non-flowing lakes up to $30 \div 40$ years old. Their depth is bigger and is $4 \div 7 \mathrm{~m}$, processes vegetation overgrow are quite expressive, but less intense than in the lakes of the 1st group, and constitute $30 \div 45 \%$.

The 3rd group - old flowing lakes aged $55 \div 60$ years of slow water exchange with connection to the river network. Their depth is $5 \div 6 \mathrm{~m}$. The overgrowth of aquatic vegetation is $30 \div 35 \%$.

The 4th group - younger flowing lakes aged $30 \div 35$ years of slow water exchange with connection to the river network. Their depth is $6 \div 10 \mathrm{~m}$, averaging about 7 meters. The overgrowth of aquatic vegetation is $10 \div 20 \%$.

The oxygen content in lakes of different groups in thickets of macrophytes during the period of observation varied in the range from 4.8 to $10.3 \mathrm{mhO}_{2} / \mathrm{dm}^{3}$ corresponding to $54 \div 121 \%$ saturation. 
Figure 2 shows the average content of dissolved oxygen in lakes of the 1st group in the macrophyte thickets and in areas with no vegetation. Saturation of oxygen in the air-water thickets of vegetation depending on the depth ranged from $54 \div 77 \%$, in the thickets of submerged vegetation $-85 \div 93 \%$, in thickets of vegetation with floating leaves $-70 \div 76 \%$, in areas without vegetation $66 \div 78 \%$. In the thickets of reeds, yellow spatter-dock, as well as in areas without vegetation the oxygen content at different depths was less than in the thickets of bushes submerged into water in $1,23 \div 3,0$ times.



Fig. 2. Average values of oxygen [\% of saturation] in the macrophyte thickets of various environmental groups in technogenic lakes in the 1st group

Rys. 2. Średni wskaźnik zawartości tlenu [\% nasycenia] w zaroślach mikrofitów różnych grup ekologicznych w jeziorach technogenicznych I grupy

Within each group, there formed a specific mode of oxygen in the water, due to the structural features of plants of different ecological groups, and therefore to the intensity of photosynthesis process. In thickets of air-water aquatic vegetation the oxygen content begins to fall sharply at a depth of $0.9 \mathrm{~m}$. In vegetation embedded to this depth the oxygen content is almost the same, and then its concentration gradually decreases. In areas with no vegetation, there is another pattern that, in our opinion, is due to the prevalence of atmospheric aeration in formation of oxygen regime in the water up to $0.5 \mathrm{~m}$.

Figure 3 shows the content of dissolved oxygen in lakes of the second group in the macrophytes thickets and in areas with no vegetation.

Saturation of oxygen in the air-water thickets of vegetation depending on the depth varies within $104 \div 108 \%$, in the thickets of submerged vegetation $106 \div 121 \%$, in the thickets of vegetation with floating leaves $-102 \div 106 \%$, and in areas without vegetation $-103 \div 105 \%$ that exceeds the results in the older non-flowing lakes and indicates lower expenses of oxygen in productive-de- 
structive dynamic processes occurring in aquatic ecosystems of this group of lakes.

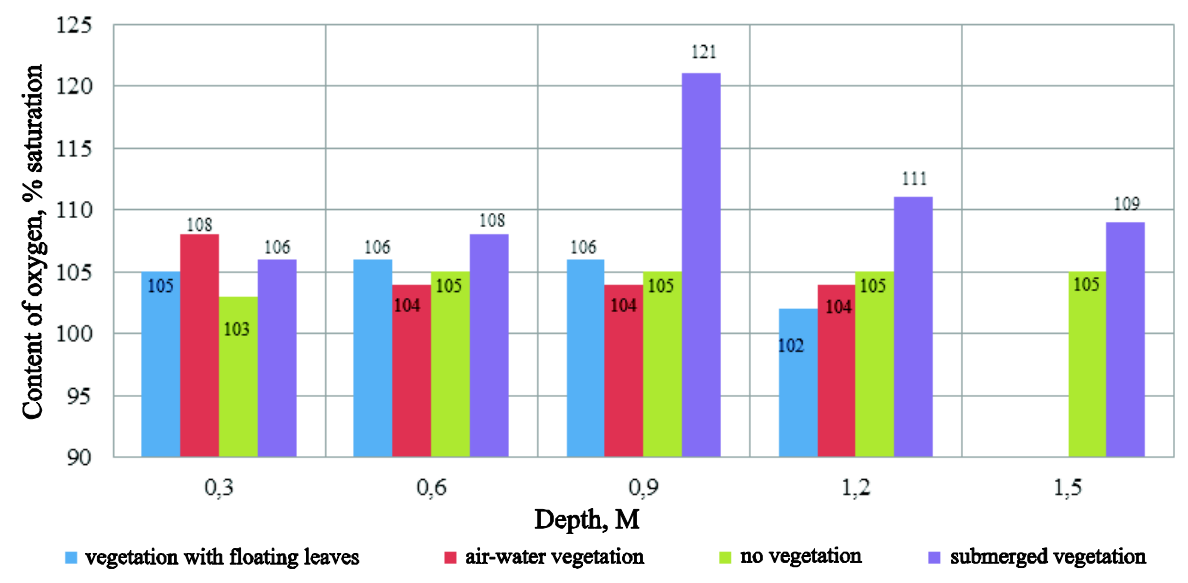

Fig. 3. Average values of oxygen content in the macrophytes thickets of different ecological groups of technogenic lakes in the 2nd group

Rys. 3. Średni wskaźnik zawartości tlenu w zaroślach mikrofitów różnych grup ekologicznych w jeziorach technogenicznych II grupy

In general, there remains a tendency of larger accumulation of oxygen in the thickets of submerged vegetation, but its maximum concentration is reached at a depth of $0.9 \mathrm{~m}$, and then gradually decreases, but at a depth of $1.5 \mathrm{~m}$ it remains the highest compared with other environmental groups $-10 \%$ more oxygen in the thickets of vegetation with floating leaves, and respectively $6 \%$ and $4 \%$ oxygen in air-water thickets of vegetation and in areas without vegetation.

The content of dissolved oxygen in lakes of the 3rd group is shown in Fig. 4. Saturation of oxygen in lakes of the 3rd group in the thickets of airaquatic vegetation depending on the depth ranges in $90 \div 99 \%$, in the thickets of submerged vegetation $-100 \div 106 \%$, vegetation with floating leaves $-85 \div 101 \%$, and in areas without vegetation $-100 \div 101 \%$. The oxygen content in the airwater thickets of aquatic vegetation and vegetation with floating leaves decreases with depth. In the thickets of submerged vegetation as well as in the lakes of the second group, there is a maximum accumulation of oxygen at a depth of $1 \mathrm{~m}$, after which its concentration gradually decreases, but the absolute values of oxygen saturation of the "old" lakes with slow water exchange (3rd group) is $5 \div 15 \%$ lower than the in «young» non-flowing lakes (2nd group).

Figure 5 shows the distribution of oxygen concentrations by depth in the macrophyte lakes of the 4th group. Oxygen saturation in the lakes of the 3rd group in the thickets of air-aquatic vegetation depending on the depth varies 




Fig. 4. Average values of the oxygen content in the macrophytes thickets of different ecological groups of technogenic lakes in the 3rd group

Rys. 4. Średni wskaźnik zawartości tlenu w zaroślach mikrofitów różnych grup ekologicznych $w$ jeziorach technogenicznych III grupy

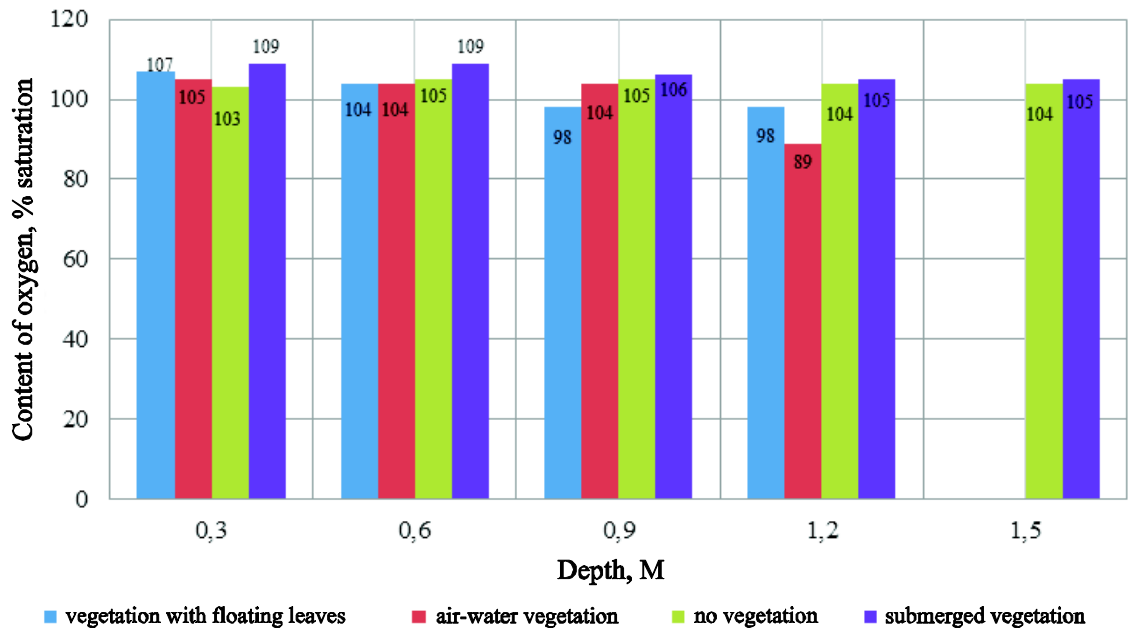

Fig. 5. Average values of oxygen content in the macrophytes of different ecological groups of technogenic lakes in the 4th group

Rys. 5. Średni wskaźnik zawartości tlenu w zaroślach mikrofitów różnych grup ekologicznych w jeziorach technogenicznych IV grupy

within $89 \div 105 \%$, in thickets of submerged vegetation $-105 \div 109 \%$ in the thickets of vegetation with floating leaves $-98 \div 107 \%$, and in areas without vegetation $-103 \div 105 \%$. The concentration of oxygen in water of man-made lakes of the fourth group is relatively high, but their distribution in depth in areas occu- 


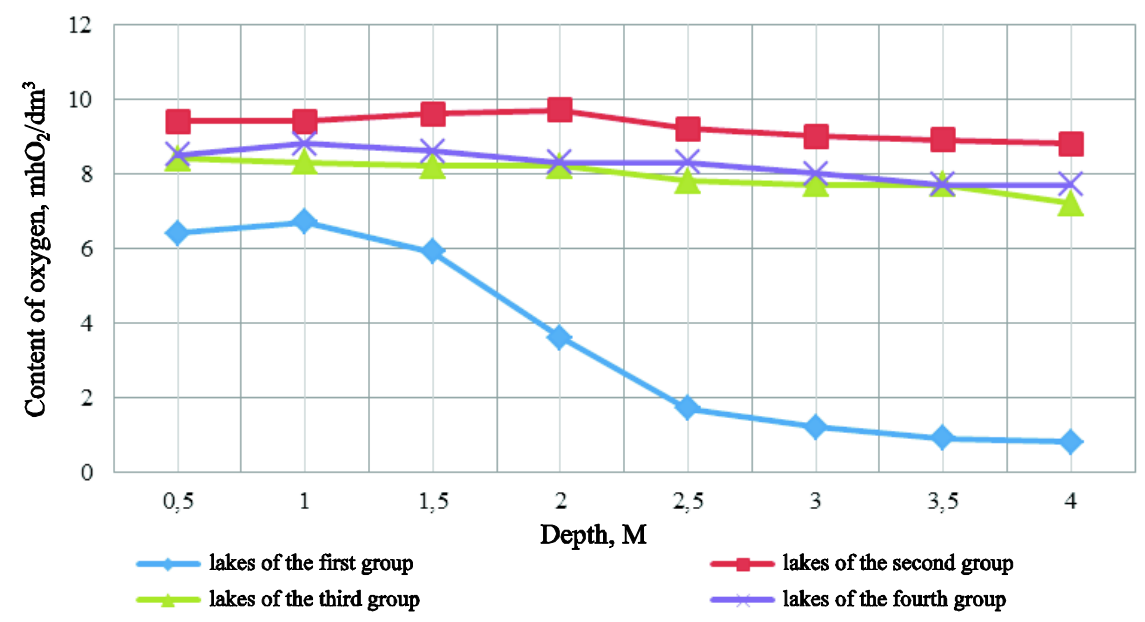

Fig. 6. Distribution of the average oxygen concentration in the depth of technogenic lakes in areas without vegetation

Rys. 6. Rozdzielczość średniej koncentracji tlenu według głębokości w jeziorach technogenicznych w częściach bez roślinności

pied by macrophytes of various environmental groups, has some differences compared to the previous two options and is similar to the oxygen content in the lakes of the 1st group, and in this case it indicates oligotrophic state of the lake.

In general, the analysis of charts and graphs shows that with depth the content of dissolved oxygen in water of man-made lakes decreases. When measuring, the lowest values were recorded in bottom layers of lakes in the 1st group (Fig. 6), where the oxygen content is reduced to $1.7 \mathrm{mhO}_{2} / \mathrm{dm}^{3}$ that allows to affirm the active development of eutrophication processes and intensive "aging" of the 1st group of lakes, as it is well known that in summer in eutrophic lakes the oxygen content decreases sharply with depth, and at the bottom its content is minimal, which was recorded in research in the areas of lakes of the 1st group.

Lakes of other groups can be attributed to oligotrophic because in the unproductive lakes the oxygen content varies slightly with depth and in the bottom its content is sufficiently high.

\section{Conclusions}

Analyzing the received data can be noted that technogenic lakes of different age which are either non-flowing or with slow water exchange have individual concentration of dissolved oxygen. Thus, the oxygen content in non-flowing lakes at the age of 60 years in the water up to $1.5 \mathrm{~m}$ makes $4,8 \div 8,1 \mathrm{mhO}_{2} / \mathrm{dm}^{3}$. In the «younger» non-flowing lakes of $30 \div 40$ years of age the oxygen concentration is the largest and makes $8,7 \div 10,3 \mathrm{mhO}_{2} / \mathrm{dm}^{3}$. 
In lakes with slow water exchange aged $55 \div 60$ years, the oxygen content is in the range of $7,5 \div 9,2 \mathrm{mhO}_{2} / \mathrm{dm}^{3}$. The same interval is typical for younger flowing lakes aged $30 \div 35$ years. Thus, the degree of accumulation of oxygen in technogenic reservoirs is affected by both age and degree flow-through lake. In macrophytes thickets of various environmental groups a specific oxygen regime is formed through the structural features of plants of different ecological groups, and therefore the intensity of the process of photosynthesis in depth is different. The highest amount of oxygen is accumulated in the lakes in the bush submerged vegetation and makes $85 \div 121 \%$ saturation. In areas of undergrowth airwater vegetation the oxygen content varies widely $(54 \div 108 \%)$ and strongly depends on the type and depth of the reservoir. A similar range of oxygen $(70 \div 107 \%$ saturation) is characteristic of undergrowth plants with floating leaves. The oxygen concentration in the last two environmental groups gradually decreases with depth. In the thickets of submerged vegetation there are two versions of the oxygen regime, the first mode (gradual decrease in concentration) - typical for water of the first and 4th groups that have lower concentrations of oxygen $(85 \div 109 \%$ ), the $2 \mathrm{nd}$ - for ponds of the second and 3rd groups with peak of oxygen accumulation at a depth of about $1 \mathrm{~m}(106 \div 121 \%$ saturation), then the oxygen content decreases with increasing depth.

The content of dissolved oxygen in the water during the summer is an important indicator of the eutrophic water degree. According to the determined data, on the lakes of the first group there is the development of eutrophication processes, as it was revealed a sharp fall in oxygen concentration with depth and its low value in the bottom layer.

\section{References}

1. Law of Ukraine „On ratification of European Landscape Convention” from 7.09.2005. N 2831-IV. Notes from Supreme Court of Ukraine, 2005, 51.

2. Kucheryavy V.P.: Reclamation and fitomelioration. Lviv, Svit 2006.

3. Kucheryavyi V.P.: Phytomelioration: Manual. Lviv, Svit 2003.

4. Sadchikov A.P.: Ecology of coastal-water vegetation (training manual for students of high schools. Publishing house NIA-Priroda, REFIA 2004.

5. Dubyna D.V., Stoyko S.M., Sytnyk K.M.: Macrophytes - the indicators for environmental changes. Naukova Dumka, 1993.

6. Krotkevych P.G.: Role of vegetation in protection of water reservoirs: Manual. Znaniye 1982.

7. Krot Y.G.: Using of up-water aquatic plants in biotechnology for cleaning of upper waters and sewage waters. Hydrobiological Journal, 42, 1, 2006, 47-61.

8. Kokin K.A.: Ecology of higher vegetation: Manual. Znaniye 1982. 
9. Gallon C., Munger C., Premont S., Campbell P.G.C.: Hydroponic study of aluminum accumulation by aquatic plants. Effects of fluoride and $\mathrm{pH}$. Water, Air, and Soil Pollution, 153, 1-4, 2004, 135-155.

10. Konstantinov A.S.: General hydrobiology. High School, 1079.

11. R. Hohmann, R. Kipfer et al.: Processes of deep-water renewal in Lake Baikal, Limnolog. Oceanogr., 42, 5, 1997, 841-855.

12. Karpova G.A.: Oxygen regime in the macrophytes thickets with different intensity of water exchange (based on the examples of flood-plain ponds of the Dnieper). Hydrobiological Magazine, 44, 4, 2008, 56-66.

13. Tsaplina E.N.: Role of higher vegetation in the oxygen regime of the water reservoirs of Ukraine. Presentation at the V All-Russian conference on water vegetation „Hydrobotanics 2000”. Borok 10-13 October 2000, 227-228.

14. Gerasimova T.N.: Interrelations between trophic chains and influence of non-ivy hydrophytes over the oxygen regime of eutrophic water reservoirs. Water Resources, 6, 1998, 724-729.

15. Einor L.O.: Special features of the oxygen regime formation and $\mathrm{pH}$ of natural water influenced by submerged vegetation in conditions of Ivankov water reservoir. Water Resources, 2, 1984, 122-131.

16. Babichenko V.N., Barabash M.B., Logvinov K.T.: Nature of Ukrainian SSR. Climate, Naukova Dumka, 1984.

17. Kucheryavy V.P.: General Ecology. Lviv, Svit 2010.

18. Pianka E.: Evolutional Ecology. Publishing House „Myr”, 1981.

\section{FITOMELORATYWNY WPEYW MAKROFITÓW RÓŻNYCH GRUP EKOLOGICZNYCH NA WARUNKI TLENOWE JEZIOR TECHNOGENICZNYCH MALEGO POLESIA UKRAINY}

\section{Streszczenie}

W pracy zostały przedstawione wyniki określenia cech warunków tlenowych w zaroślach makrofitów różnych grup ekologicznych, do których są zaliczane zanurzone (Ceratophyllum demersum L.), pływające (Potamogeton natans L., Nuphar lutea (L). Smith.) i powietrzno-wodne rośliny (Phragmites australis (Cav.) Trin. ex Steud.) rosnące w jeziorach technogenicznych Małego Polesia Ukrainy. Teren fizyczno-geograficzny Małego Polesia znajduje się w większości na zachodniej części Ukrainy i na niewielkiej wschodniej części Polski. Są to tereny płaskie, o wysokim stopniu wilgotności, wykształcone w niewielkiej odległości od powierzchni wód podziemnych. Jeziora technogeniczne na tym obszarze zostały utworzone w wyniku wydobywania piasku z wykorzystaniem pogłębiarki w warunkach wodnych kanionów przed 30-60 laty. Jeziora można zaliczyć zarówno do jezior przepływowych, jak również do zamkniętych. Tlen rozpuszczony, temperatura oraz nasycenie tlenem było mierzone na różnych głębokościach za pomocą narzędzi Oxi 330s/SET. Największe koncentracje tlenu wykryto w częściach jezior zajętych roślinnością zanurzoną. W powietrzno-wodnych zaroślach oraz wśród roślinności pływającej zawartość tlenu jest prawie jednakowa. Ten wskaźnik stopniowo się zmniejsza wraz z głębokością. Na warunki tlenowe w zaroślach makrofitów wpływa wiek i przepływalność jezior. Koncentracja tlenu największa jest w stosunkowo „młodszych” nieprzepływowych jeziorach (30-35-letnich), najmniejszą zaś w starszych jeziorach, które cechuje największy stopień zarośnięcia. Według rezultatu pomiaru tlenu rozpuszczonego na różnych głębokościach i przy warstwie 
dolnej ustalono aktywny rozwój procesów eutrofizacji w nieprzepływowych jeziorach technogenicznych przez ok. 60 lat.

Słowa kluczowe: zawartość tlenu, jeziora technogeniczne, zanurzone, pływające powietrzno-wodne makrofity

DOI:10.7862/rb.2013.62

Przestano do redakcji 10.10.2013 $r$.

Przyjęto do druku: 13.11.2013 r. 